\title{
MAKING STRATECY WORK: THE ROLE OF THE MIDDLE MANAGER
}

\author{
Prof Mari Jansen Van Rensburg; Prof Annemarie Davis and Prof Peet Venter
}

\begin{abstract}
In recognition of middle managers as influential strategists we collected 654 responses from South African middle managers detailing their spontaneous and unguided descriptions of their strategic roles in the organisation they represent. The results show that middle managers generally associate their strategic role strongly with the traditional perspectives on the roles as implementers of strategies and communicators linking their subordinates and higher levels of management. We add the roles of 'advocacy' and 'improving operational performance' to the conventional elements of strategy implementation, and the roles of 'managing performance' and 'driving compliance' to the role of downward influence. Focus group discussions contextualised and authenticated these roles within the South African private and public sectors.
\end{abstract}

Keywords: middle managers, strategic roles, strategy-as-practice

\section{INTRODUCTION}

In the past 2 decades we observed significant shifts in the perceptions of the roles and structures of the traditional management cadre. Moving beyond the truncated views of strategy as deliberate, top-down processes, the practice turn in management led to strategy scholars acknowledging a much wider group of actors as strategists (Jarzabkowski, Balogun, \& Seidl, 2007). The practices associated with strategising have also become more prominent in the current dynamic business environment. However, these new roles and structures are not part of traditional management perspectives that privilege the more rational microeconomic views of strategy at the cost of human perspectives. In the light of perspectives on strategy making as a human activity (as opposed to being an organisational process), middle managers are recognised as influential strategic actors (Currie \& Procter, 2005; Mantere, 2008; Wooldridge, Schmidt, \& Floyd, 2008). By identifying middle managers as strategists, the strategy research agenda expands beyond top managers (Rouleau, 2005; Balogun, 2007). It was the seminal work of Floyd and Wooldridge (1994: 48) that inspired discourse on the role of the middle manager when they referred to the 'misunderstood middle manager'. Traditionally, academic literature in strategic management predominantly focused on the actions and decisions of top managers. Other managers were considered to be the administrators or implementers (often termed executors) of these decisions. In this capacity, middle managers were responsible for organising, directing and controlling predetermined plans (Huy, 2001). The realisation of redefined and realigned strategic roles at various levels of management created a new body of knowledge confirming that middle managers have a substantive influence on the strategy-making process, strategising activities and company performance (Floyd \& Wooldridge, 2000, 2003; Huy, 2001, 2002; Balogun \& Johnson, 2004; Carney, 2004, Ikävalko, 2005; Mantere, 2005, 2008; Costanzo \& Tzoumpa, 2008; Nordqvist \& Melin, 2008; Wooldridge, Schmid, \& Floyd, 2008; Raes, Heijltjes, Clunk, \& Roe, 2011; Rouleau \& Balogun, 2011).

This more substantive position for middle managers as strategists recognises that middle managers may have the knowledge and experience to connect divergent ideas generated from outside and within the organisation to strategic issues (Floyd \& Wooldridge, 2000). Middle managers are also acknowledged as being mediators acting between different levels and units (Balogun \& Johnson, 2004). Finally, there is consensus that strategising is being decentralised (Wooldridge, Schmid, \& Floyd, 2008). However, while researchers seem to agree on a broader strategic role for middle managers, little is known about how middle managers perceive their own strategic roles, which provides the purpose of this article.

In exploring the research question: 'How do South African middle managers perceive their own strategic roles?' this article provides an integrated account of the literature on the strategic roles of middle managers. The literature review is followed by an overview of the findings detailing the self-identified strategic roles of middle managers in South Africa. In a quest to clarify the self-perceived roles of middle managers, we conducted exploratory research among 654 South African middle managers. Not only were we interested in establishing how middle managers view their own role in making strategy work in their organisational context, but also in exploring how these perspectives differ from traditional theoretical perspectives. Findings from this research can advance our understanding of middle manager strategising, as previous strategy-as-practice research has focused on conceptually identifying middle manager roles from the perspective of researchers rather than from the perspective of middle managers. In addition, the South African and emerging market context offers an interesting perspective in a field where research conducted in the developed world is dominant. The article concludes with a discussion of the theoretical and managerial implications and directions for future research. 


\section{LITERATURE OVERVIEW}

The recognition of strategic roles of middle managers can be mainly attributed to three changes in the management environment. First, more organisations decentralise their organisational structures and make managers, lower in the hierarchy, responsible for strategic decisions. Second, managers are better trained and more able and eager to participate in strategy. Third, the shift away from a traditional manufacturing economy to one based on professional services means that the key sources of competitive advantage are now found in the knowledge of people who are involved in the operations of the business (Johnson, Whittington, \& Scholes, 2011). Middle managers at operational level understand and influence these knowledge-based sources of competitive advantage better than remote top managers. In addition, the nature of the contemporary environment complicates the strategic management as the time and information to analyse and execute a carefully conceived strategy are often not available. The view that the middle manager's role in strategy goes beyond merely implementing top-down strategies has thus developed over years in response to a changing business environment. As such, Floyd and Wooldridge (2000: 15) contend that strategy making is a middle-level social learning process. The following section offers an integrated interpretation of the role of middle managers in strategic management.

\section{The middle manager}

Despite the fact that the term 'middle manager' is well established in literature, one would not commonly find people with the job title 'middle manager' in organisations. Instead, the position of a middle manager rather refers to an operational function or hierarchal placement. Several conceptualisations of the term have been proposed. Authors have described middle managers by using operational descriptions such as the 'assistant of authority' (Mills, 1956: 9); 'functioning as mediators between the organisation's strategy and day-to-day activities' (Nonaka, 1994: 14) and 'managing a set of team leaders' (Osterman, 2008: 5). Other authors base their description on actual positions in the organisational chart such as 'any manager below the CEO and one level above line workers and professionals' (Huy, 2001: 72) or 'managers who operate in the "middle" of the organisational hierarchy' (Floyd \& Wooldridge, 1992: 157). Ikävalko (2005) describes middle managers as those actors who act as both subordinates and superiors. Floyd and Wooldridge (1992) state that middle managers link the activities of vertically related groups and are responsible for at least sub-functional workflow, but not for the workflow of the organisation as a whole. We consider access to top management coupled with knowledge of operations as key determinants for someone to be considered a middle manager. The description we used in this research project was: "Middle managers have managers reporting to them and are also required to report to managers at a more senior level'.

\section{Integrated account of the literature on the strategic roles of middle managers}

Literature not only recognises the important role of middle managers as implementers but also acknowledges the value of middle managers as linking pins who have upward, downward and lateral influence. Table 1 presents a summary of the roles and strategising activities identified in previous research, in chronological order. Column 2 in Table 1 reflects the roles identified in the studies. Our research was grounded in the strategy-as-practice perspective (Whittington, 2003; Jarzabkowski, 2005; Johnson, Langley, Melin, \& Whittington, 2007) with a focus on strategy as 'something that people do' (Jarzabkowski, 2004: 529). As such, in column 3 of Table 1, we identified the roles in a verb form to link the activities to the roles played out in practice (Jarzabkowski, 2003). This approach has the potential to uncover grey areas, previously unexplored in approaches used to frame the labour of strategising (Carter, Clegg, \& Kornberger, 2008).

In order to visualise changing roles, the activities listed in column 3 in Table 1 were imported into Wordle (a software program) to generate a 'word cloud' from the text. McNaught and Lam (2010) found that Wordle is particularly useful for studies that involve qualitative or thematic analyses of written or transcribed spoken text. The word cloud, presented as Figure 1, contains the most prominent activities associated with middle management roles. The most conspicuous activities are presented in a larger font size (McNaught \& Lam, 2010). Our research led deductive perspective identified the most prominent themes to describe the strategic roles of middle managers as implementing strategies, interpreting and communicating information, facilitating adaptability, supporting downward and influencing upward. Each of these themes is discussed below by means of linkages to existing identified roles in the literature. 


\section{Implementing strategies}

The importance of the middle manager's role in implementing strategy has been advocated for many years. Floyd and Wooldridge (1992) define this role as managerial interventions that align organisational action with the strategic intentions of top management. Middle managers implement strategy by translating corporate strategy into action plans and individual objectives (Currie \& Procter, 2005: 1325). Briggs (2005: 27) refers to this role as 'making it happens'. Ikävalko (2005) suggests that 'executing the intended strategy' can be linked to an intention of getting people to implement the deliberate strategy. Chia and Holt (2006: 643) explain that in the case of deliberate strategy, there is much greater clarity of understanding about what is expected in terms of explicit purposes. Here the role of the middle manager is more related to compliance with strategic rules. Middle managers, according to Raes et al. (2011), are central to effective strategy implementation.

Table1. C hronological summary of roles identified in previous research and the manually assigned strategic activities

\begin{tabular}{|c|c|c|}
\hline STUDIES/YEAR & ROLES IDENTIFIED & STRATEGIC ACTIVITIES \\
\hline Burgelman (1983) & $\begin{array}{l}\text { Initiator } \\
\text { Implementer }\end{array}$ & $\begin{array}{l}\text { Implementing strategies } \\
\text { Upward influencing }\end{array}$ \\
\hline Nonaka (1988) & $\begin{array}{l}\text { Innovator } \\
\text { Implementer }\end{array}$ & $\begin{array}{l}\text { Implementing strategies } \\
\text { Interpreting and communicating }\end{array}$ \\
\hline Westley (1990) & $\begin{array}{l}\text { Communicator } \\
\text { Implementer }\end{array}$ & $\begin{array}{l}\text { Upward influencing } \\
\text { Implementing strategies }\end{array}$ \\
\hline Floyd and Wooldridge (1992) & $\begin{array}{l}\text { Champion of alternatives } \\
\text { Synthesiser of information } \\
\text { Facilitator of adaptability Implementer of } \\
\text { deliberate strategy }\end{array}$ & $\begin{array}{l}\text { Interpreting and communicating } \\
\text { Facilitating adaptability } \\
\text { Implementing strategies } \\
\text { Upward influencing }\end{array}$ \\
\hline Dutton and Ashford (1993) & Issue seller & Upward influencing \\
\hline $\begin{array}{l}\text { Dutton, Ashford, O’Neill, Hayes, } \\
\text { and Wierba (1997) }\end{array}$ & Issue seller & Upward influencing \\
\hline Floyd and Wooldridge (1999) & $\begin{array}{l}\text { Builder and integrator of knowledge } \\
\text { domains, social networks and resources } \\
\text { Implementer }\end{array}$ & $\begin{array}{l}\text { Implementing strategies } \\
\text { Interpreting and communicating }\end{array}$ \\
\hline $\begin{array}{l}\text { Dutton, Ashford, O'Neill, and } \\
\text { Lawrence, (2001) }\end{array}$ & Issue seller & Upward influencing \\
\hline Huy $(2001)$ & $\begin{array}{l}\text { Entrepreneur } \\
\text { Communicator } \\
\text { Therapist } \\
\text { Tightrope artist }\end{array}$ & $\begin{array}{l}\text { Implementing strategies } \\
\text { Facilitating adaptability } \\
\text { Downward supporting }\end{array}$ \\
\hline Huy (2002) & $\begin{array}{l}\text { Emotional balancer } \\
\text { Helper of others to adapt } \\
\text { Downward supporting } \\
\text { Implementer }\end{array}$ & $\begin{array}{l}\text { Implementing strategies } \\
\text { Facilitating adaptability }\end{array}$ \\
\hline Marginson (2002) & Prioritiser & $\begin{array}{l}\text { Implementing strategies } \\
\text { Facilitating adaptability }\end{array}$ \\
\hline O'Shannassy (2003) & Implementer & Implementing strategies \\
\hline Currie and Procter (2005) & $\begin{array}{l}\text { Translator of corporate strategy into action } \\
\text { plans and individual objectives }\end{array}$ & $\begin{array}{l}\text { Implementing strategies } \\
\text { Interpreting and communicating } \\
\text { Facilitating adaptability }\end{array}$ \\
\hline Briggs (2005) & $\begin{array}{l}\text { Corporate agent } \\
\text { Implementer } \\
\text { Staff managers } \\
\text { Leader } \\
\text { Liaison }\end{array}$ & $\begin{array}{l}\text { Facilitating adaptability } \\
\text { Implementing strategies } \\
\text { Downward supporting } \\
\text { Interpreting and communicating }\end{array}$ \\
\hline \multirow[t]{2}{*}{ Ikävalko (2005) } & $\begin{array}{l}\text { Empowerer } \\
\text { Reflector } \\
\text { Facilitator } \\
\text { Implementer of intended strategy }\end{array}$ & $\begin{array}{l}\text { Downward supporting } \\
\text { Interpreting and communicating } \\
\text { Facilitating adaptability } \\
\text { Implementing strategies }\end{array}$ \\
\hline & & $\begin{array}{l}\text { Downward supporting } \\
\text { Interpreting and communicating } \\
\text { Facilitating adaptability } \\
\text { Implementing strategies }\end{array}$ \\
\hline Kodama (2005) & $\begin{array}{l}\text { Builder of strategic networks } \\
\text { Leader }\end{array}$ & Downward supporting \\
\hline $\begin{array}{l}\text { Kuratko, Ireland, Covin, and } \\
\text { Hornsby (2005) }\end{array}$ & $\begin{array}{l}\text { Entrepreneur } \\
\text { Resource allocator }\end{array}$ & $\begin{array}{l}\text { Downward supporting } \\
\text { Implementing strategies }\end{array}$ \\
\hline
\end{tabular}




\begin{tabular}{|c|c|c|}
\hline Ling, Floyd, and Baldridge (2005) & $\begin{array}{l}\text { Socialiser } \\
\text { Issue seller }\end{array}$ & $\begin{array}{l}\text { Downward supporting } \\
\text { Upward influencing }\end{array}$ \\
\hline Mantere (2005) & $\begin{array}{l}\text { Strategic champion } \\
\text { Implementer }\end{array}$ & Implementing strategies \\
\hline Rouleau (2005) & $\begin{array}{l}\text { Sensemaker } \\
\text { Sensegiver } \\
\text { Implementer of change }\end{array}$ & $\begin{array}{l}\text { Interpreting and communicating } \\
\text { Facilitating adaptability } \\
\text { Implementing strategies }\end{array}$ \\
\hline Chia and Holt (2006) & Clarifier of what is expected & $\begin{array}{l}\text { Implementing strategies } \\
\text { Interpreting and communicating } \\
\text { Downward supporting }\end{array}$ \\
\hline Herzig and Jimmieson (2006) & $\begin{array}{l}\text { Implementer } \\
\text { Supporter } \\
\text { Facilitator of communication between senior } \\
\text { management and employees }\end{array}$ & $\begin{array}{l}\text { Implementing strategies } \\
\text { Downward supporting } \\
\text { Facilitating adaptability }\end{array}$ \\
\hline Costanzo and Tzoumpa (2008) & $\begin{array}{l}\text { Knowledge integrator } \\
\text { Implementer }\end{array}$ & $\begin{array}{l}\text { Facilitating adaptability } \\
\text { Implementing strategies }\end{array}$ \\
\hline Mantere and Vaara (2008) & $\begin{array}{l}\text { Narrator } \\
\text { Resource allocator } \\
\text { Referee }\end{array}$ & $\begin{array}{l}\text { Interpreting and communicating } \\
\text { Implementing strategies } \\
\text { Upward influencing }\end{array}$ \\
\hline Nordqvist and Melin (2008) & $\begin{array}{l}\text { Social craftsman } \\
\text { Implementer }\end{array}$ & $\begin{array}{l}\text { Interpreting and communicating } \\
\text { Implementing strategies } \\
\text { Facilitating adaptability }\end{array}$ \\
\hline Raes, Heijltjes, Glunk, \& Roe (2011) & Implementer of strategy & Implementing strategies \\
\hline Rouleau and Balogun (2011) & $\begin{array}{l}\text { Sensemaker } \\
\text { Implementer of change strategies }\end{array}$ & Interpreting and communicating \\
\hline
\end{tabular}

The role of strategy implementation is clearly established in the traditional perspectives of strategic management that considers strategy as a top-down process where formulation is separated from implementation, predisposing a focus upon top managers (Karger \& Malik, 1975; Hambrick \& Mason, 1984; Van de Ven, 1992; Wiersema \& Bantel, 1992; Papadakis, Lioukas, \& Chambers, 1998; Carpenter, 2002; Hambrick, 2007; Lyles \& Schwenk, 2007). In contrast, contemporary management perspectives hold that the middle manager's role has changed from being an order transmitter to a more active participant in strategy formation and that they have become boundary spanners who facilitate strategic conversations and information flows (O'Shannassy, 2003).

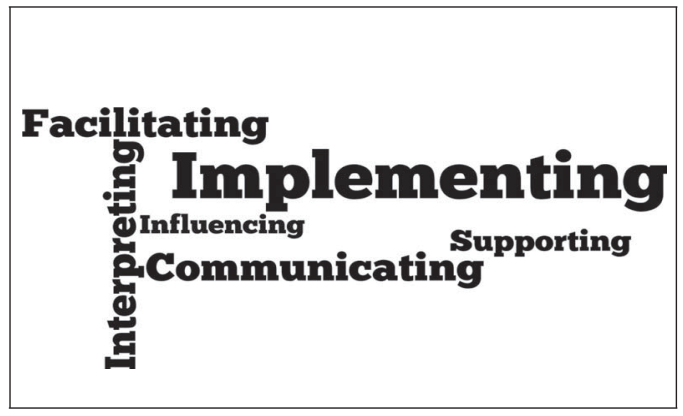

Figure 1. The most prominent strategic activities of middle managers

Interpreting and communicating information

Regarding the middle manager's role as a facilitator of strategic conversations and information flow, the second theme identified in the literature is 'interpreting and communicating information'. Considering various activities associated with information we identified four recurring strategising activities, namely synthesising information, sense making, sense giving and communication. Middle managers are often expected to interpret and channel information about outside market pressures and internal sensitivities and capability upward (Huy, 2001). The way in which this information is synthesised affects top management perceptions and can subsequently influence the formulation of strategy (Floyd \& Wooldridge, 1992). Middle managers also apply their experience to evaluate the relevance and feasibility of proposed corporate strategic initiatives and changes. Their interpretations are then used to frame information communicated to subordinates (Dutton, Ashford, O’Neill, \& Lawrence, 2001; Huy 2001). Synthesising information is thus defined as the interpretation, evaluation and compilation of information. The synthesising role is closely related to the 'artful interpreter role' (Nordqvist \& Melin, 2008: 326). The artful interpreter interprets and combines localised adaptations with the generalised security and support provided by the strategic planning practice in use. 
In order to explain how middle managers interpret and sell strategic change at the organisational interface, Rouleau (2005: 1413) considered the workings of primary sense making and sense giving micro-practices. Sense making is defined as a social process of construction and reconstruction of meaning through which managers understand, interpret and create sense for themselves and others about their changing organisational context and surroundings (Rouleau \& Balogun, 2011). When middle managers influence the way in which an issue is being understood and enacted, they engage in sense giving. The importance of these activities is emphasised by Dutton, Ashford, O'Neill, Hayes, and Wierba (1997) who assert that middle managers shape organisational accounts by sense giving to their leaders and subordinates. Other activities associated with sense making and sense giving are narrating and facilitation. Narrating encompasses both the telling and the told (Barry \& Elmes, 1997), while facilitating refers to the intention of making people understand the intended strategy (lkävalko, 2005). Both these activities involve the practices to clarify the verbal communication or prepared material about formal strategic choices. This entails explaining the details of the strategy and describing what the big picture is behind the choices in strategy.

Middle manager roles often involve 'spreading the word' (Huy, 2001: 76). Although this activity is related to the role of synthesising information, communication as an identified action refers to the activity of sharing information and excludes the formulation of the message or the medium of transfer. According to Floyd and Wooldridge (1992: 155) middle managers supply information to top management concerning internal and external events. Middle managers also communicate with subordinates. In this capacity, Floyd and Wooldridge (2000) refer to middle managers as 'linking pins' in hierarchical networks. As a communication link they often serve as the starting point for action to be taken by upper and lower levels (Nonaka, 1988). According to Briggs (2005: 32) middle managers are bridges between senior management and the work teams. In a position where they have the knowledge and experience to connect divergent ideas generated from within the organisation to strategic issues (Floyd \& Wooldridge, 2000), the theme of interpreting and communicating information confirms the importance of middle managers as strategic actors.

\section{Facilitating adaptability}

Middle managers can exert a downward influence through 'facilitating adaptability' where they support more radical activities within the areas they manage that lie outside top management's official expectations (Currie \& Procter, 2005: 1325). Briggs (2005: 32), who calls this role of being the 'corporate agent', explains that middle managers facilitate adaptability as they work within and set up the management systems. Nordquist and Melin (2008: 329) refer to this role as being the 'social craftsperson', since the middle manager takes the initiative to foster flexible organisational arrangements that result in strategic changes. Middle managers are expected to promote experimentation and autonomous development within their areas of responsibility. This expectation is placed on middle managers with the aim of work practices being adapted to the changing environment (Floyd \& Wooldridge, 1992: 155). Mantere and Vaara (2008: 306) contend that the expectation to facilitate adaptability also has the potential to enable strategic agency on the part of the middle manager. In a dynamic business environment, adaptability is furthermore obtained by a participative approach to strategy formulation welcoming middle managers as strategy formulators (Rouleau, 2005). As social actors, middle managers also facilitate knowledge integration and transfer across teams and organisational boundaries to enhance organisational practice (Costanzo \& Tzoumpa, 2008).

\section{Downward s upporting}

For the purpose of our research, we proposed that the supporting role incorporates emotional balancing, attending to the change recipients' need for continuity and professional support. Huy (2001) explains that uncertainty about change can deflate morale and trigger anxiety in organisations. Once people are depressed, they stop learning, adapting or helping to move the group forward. He argues that senior managers cannot do much to alleviate the pain as they are too far removed from most workers. However, middle managers have no choice but to address their employees' emotional well-being. The therapist role, identified by Huy, highlights the important task of middle managers to address their employees' emotional well-being. They do a host of things to create a psychologically safe work environment and they are able to do this because of their position within the organisation. Huy (2002) also refers to an emotional balancing process where middle managers help people make sense of, and cope with, change. This 'practical coping' (Chia \& Holt, 2006) is made possible through local improvisation. According to Chia and Holt, action often takes place non-deliberately, and strategy emerges through the internalised predisposition to act and adapt unthinkingly to local contingent demands. 
Downward support is also provided to subordinates by means of professional support that enables and empowers staff members to execute their agreed tasks successfully. According to Briggs (2005: 32) middle managers organise, monitor and evaluate the work of staff and often act as role models fulfilling the roles of a 'staff manager' and the 'leader'. In discussing the 'empowering' role, lkävalko (2005) contends that empowering does not emphasise the implementation of the current, intended strategy, but instead refers to actions that strive to evaluate and even challenge the existing strategy. Empowering thus refers to the intention of making people proactive in taking the initiative and interacting with the environment. By encouraging subordinates to contrast environment and strategy, the aim is to seek signals for change.

\section{Upward influencing}

Not only are middle managers in the position to reform the lives of staff members reporting to them through emotional and professional support but they also have the potential to reshape the strategic thinking of top management by selling strategic initiatives to them that diverge from their current conception of strategy. Burgelman (1983) found that middle managers frequently become organisational champions for initiatives developed at the operating level. Floyd and Wooldridge (1992: 155) define the term 'championing alternatives' as the persistent and persuasive communication of strategic options to upper management. This role is distinct from facilitating adaptability as it centres on influencing corporate management to adjust their current concept of strategy (Dutton \& Ashford, 1993). Furthermore, by proposing and defining issues for top managers, middle managers provide important contributions to an organisation's strategic direction and thereby influence organisational effectiveness (Dutton et al., 1997). Mantere (2005), who also investigated the strategic champions, opted to treat the championing activity in terms of the management position and not the role. His extensive study describes strategy champions as organisational members who try to influence strategic issues in a way that extends beyond their immediate and primary operational responsibilities and the expectations of others. Mantere and Vaara (2008) confirm the conclusion of Westley (1990) that the championing expectation is subject to inclusion: when top managers invite and expect middle managers to participate in planning, the middle managers gain more control over the future.

In concluding this review, it is fitting to remember Mantere's (2008: 312) declaration:

'Organisations do not create, implement or renew strategies. People do'. Competent and active middle managers are considered to be strategic resources in theory, but we wanted to explore this proposition in practice. In particular, the exploration of extant literature suggests that previous research has focused on inductive research privileging the interpretations of middle manager actions and discourse by researchers, whereas we were interested in how middle managers view and describe their own role in strategy making. In the next section we explain how we set about our exploration of the self-perceived roles of South African middle managers.

\section{METHODOLOGY}

The findings reported in this article are part of a larger study that investigated the roles and practices of middle managers in South African organisations. This research used an interpretive approach, acknowledging that middle manager roles reflect 'the complex world of lived experience' (Schwandt, 1998: 221). An exploratory design guided the collection of qualitative data in two phases. Data collected by means of qualitative interviews in phase one and focus groups in phase two were analysed through content and thematic analysis. The findings do not aim at providing scientific or rational generalisation, but rather seek to offer insight which may be applicable elsewhere. Findings reported on in this article, specifically address the research question of 'How do South African middle managers perceive their own strategic roles?' The aim of the analysis was to identify the self-perceived roles of middle managers in the South African content and the extent to which it overlaps with extant research in this area. The aim was to provide a theoretical understanding of middle manager roles in the South African context that reflects the richness, dynamism and complexity of the data and the context, and can be useful to others.

\section{Research participants}

The unit of analysis for this study was South African middle managers. Middle managers were defined as managers who operate in the 'middle' of the organisation. In terms of organisational structure, it was required that such individuals have managers reporting to them, and that they also report to managers at a more senior level. During phase one, data were collected by 4th-year students enrolled for a business management bachelor's degree offered by a South African open and distance learning university. These students were required to select and interview one middle manager based on clearly defined respondent parameters as part of formative assessment for a strategic management course. Students registered at this institution mostly study part-time and reside across South Africa. As most students are employed either fulltime or part-time most had access to suitable middle managers at their place of employment. To enhance the 
credibility of the study, students were required to submit the personal and contact details of the respondent, a profile of the company which the respondent represented, as well as a letter from the respondent that acknowledged that the information contained in the transcript was a true reflection of the interview. Participants were contacted at random to confirm their participation by the research team. The research was conducted under the supervision of three academics responsible for the strategic management module. New roles identified, during phase one, and were further explored in focus group discussions moderated by the authors in phase two. The 12 participants of the first focus group were middle managers employed in the public sector and the eight participants of the second group were middle managers employed in the private sector. Focus group composition followed the demographic profile of participants consulted during the first phase of the study. Findings were used as part of a data triangulation process to provide validation and crystallisation (Janesick, 2000) of the new roles. Participants of the focus groups also provided rich data to contextualise these roles in the South African business and public context.

\section{Data production and analysis}

The data set from which roles and strategic activities were identified, during phase one, consisted of 674 structured interviews with middle managers representing 487 organisations and public entities. The overarching topic of the interview was the middle manager's experience with strategic management. This topic was supported by five open-ended questions dealing with different strategic management issues. This article reports on the fourth question: "What is your role to make strategy work in your organisation? Give specific examples, where possible'. Interviewers were instructed not to probe or pursue specific matters but rather to allow the respondent to give a spontaneous answer in order to determine their own unguided perception of their strategic roles. Interview texts, provided rich descriptions and had a freeflowing and open flavour. The question format allowed comparability of different responses drawn from many individuals from many organisations. Transcripts were analysed to ensure that the data considered for analysis would not compromise content validity. New roles uncovered from the analysis were validated during phase two of the study. During this phase two, HR focus groups were conducted to obtain the views from 20 South African middle managers, representing public and private sectors. New roles were introduced to the participants and discussions centred on managers' perspectives and experiences with each role. Participants were also requested to provide specific examples of instances where they assumed these roles within their management positions. Transcripts of the focus groups were used to validate and contextualise new roles uncovered from the first data set.

In both data sets, content and thematic analyses of the transcripts were performed to find patterns and themes (Creswell, 2013). These methods provided the opportunity to describe patterns across qualitative data in an attempt to identify, analyse and report patterns within data to understand participants' everyday experiences of reality in detail (Braun \& Clarke, 2006). During phase one, first-order analysis was done in order to make sense of the phenomena under investigation. We each independently reviewed 50 transcripts and marked meaningful units for analysis using pre-existing coding categories, based on the strategic activities listed in Table 1, and identified additional emergent categories as they came up. The independently developed coding categories were then compared and refined to create typologies of practices describing different roles of middle managers. We subsequently embarked on second-order coding using standardised codes to analyse the transcripts. Data saturation occurred after 100 interviews were coded, although we analysed all the transcripts in order to quantify the frequency at which codes occurred. The three sets of data were analysed for consistency and presented to describe themes and trends. During phase two, data were again reviewed independently for consistency. Findings were compared and combined with the aim to crystalise and validate the new roles uncovered.

\section{Quality and rigour}

The reliability criterion for qualitative research focuses on identifying and documenting recurrent accurate and consistent (homogeneous) or inconsistent (heterogeneous) features as patterns, themes, world views and any other phenomena under study in similar or different human contexts (Labuschagne, 2003: 103). In the case of this research study, the aim was to identify and document middle managers' roles in making strategy work. Participants provided 'self-reports' about their behaviour. In order to improve quality and rigour, participants were required to write a formal letter to confirm that transcripts were a true reflection of their interview. An auditing process was also followed to eliminate any suspect transcript by reviewing company profiles and contacting participants at random to confirm their participation in the study. Transcripts of 20 participants were discarded where participants clearly did not adhere to the definition of a middle manager or in cases where the company that the respondent represented could not confirm the respondent's position or employment. 
Coding was done collaboratively and followed the prescriptions of Saldañ a (2009). The iterative process of discussion and comparing findings and moving to and fro between data and theory contributed to crystallisation. Furthermore, the research study conformed to the accepted norms and values of research ethics (Mouton, 2006). Participant's voluntary signed informed consent documents were informed about the purpose of the assignment as well as the research study and were assured that their information would be treated as confidential. During phase two, data obtained from focus groups were used to facilitate validation of new roles uncovered. Triangulation was thus employed to explain more fully, the richness and complexity of human behaviour by studying it from more than one standpoint (Cohen, Manion \& Morrison, 2000).

\section{FINDINGS}

The findings from this research confirmed the extended roles of middle managers as presented in the literature review. The four roles observed from the data, which are presented next, provide an overview of key insights as well as strategising activities associated with each role.

\section{A profile of the research participants}

The findings that follow are based on responses from 654 South African middle managers representing 480 private sector organisations (55.5\%) and public sector entities and departments (44.5\%) obtained during phase one of the research study. During phase two, perspectives expressed during focus group discussions were considered from 20 additional middle managers employed in the public and private sectors.

Table 2. The role of implementing strategy

\begin{tabular}{|c|c|}
\hline Strategising activity & Examples from data \\
\hline Executing strategic plan & $\begin{array}{l}\text { 'I am deeply involved in implementing the chosen strategy } \\
\text { and making it work as planned. I understand the internal } \\
\text { requirements for successful strategy implementation and insist } \\
\text { that careful attention be paid to the details required for first } \\
\text { rate execution of the chosen strategy' }\end{array}$ \\
\hline $\begin{array}{l}\text { Translating and aligning objectives and } \\
\text { targets to own operational plan }\end{array}$ & $\begin{array}{l}\text { 'My role is to make sure my plans, activities and resources, and } \\
\text { pace of delivery is designed to support the overall strategy' }\end{array}$ \\
\hline $\begin{array}{l}\text { Resourcing - allocating resources to } \\
\text { support the strategic plan }\end{array}$ & $\begin{array}{l}\text { 'Translate plan into actions - include planning resources to best } \\
\text { fit our requirements' }\end{array}$ \\
\hline $\begin{array}{l}\text { Complying with own key performance } \\
\text { areas - referring to the middle manager's } \\
\text { own operational key performance areas }\end{array}$ & $\begin{array}{l}\text { (As manager it is my role) to attract and retain talent with } \\
\text { regard to recruitment. To ensure fairness in accordance to IR } \\
\text { [Industrial Relations]. To manage the employee life cycle. } \\
\text { Performance reviews of employees. Advisory capacity for line } \\
\text { managers and employees' }\end{array}$ \\
\hline $\begin{array}{l}\text { Monitoring and controlling performance } \\
\text { and compliance }\end{array}$ & $\begin{array}{l}\text { 'Then there are projects, with timelines and regular } \\
\text { feedback sessions are held for reporting back on these. } \\
\text { Also progress reports are prepared." }\end{array}$ \\
\hline $\begin{array}{l}\text { Advocacy - selling the plan to internal } \\
\text { and external stakeholders }\end{array}$ & $\begin{array}{l}\text { 'As a deputy head I am responsible for implementing and } \\
\text { explaining new strategic plans and formulation to all the staff } \\
\text { members and to ensure that there is buy-in in the process' } \\
\text { '...my role extends to promoting [name of medical aid } \\
\text { company]'s initiatives to our contracted service providers such } \\
\text { as pharmacies and biokineticist networks who are responsible } \\
\text { for conducting } \\
\text { the preventative care services' }\end{array}$ \\
\hline Improving operational practice & $\begin{array}{l}\text { 'I am the head of my division and it is entirely my } \\
\text { responsibility to find the ways and means to improve where } \\
\text { we are with our business and how we can do more to drive } \\
\text { profit. I look at how our division is structured and then apply } \\
\text { thinking and logic to how this can be improved and if } \\
\text { necessary will restructure the way that we are working with } \\
\text { our clients' }\end{array}$ \\
\hline
\end{tabular}




\section{The middle manager as an implementer of strategy}

The role of being an implementer of strategy was described; during phase one, by 451 (69\%) participants. To identify strategising activities, themes were identified where the transcript narrative explicitly linked strategising activities to the implementation role. Seven strategising activities were identified and presented in Table 2. Table 2 also contains selected verbatim quotes from data to illustrate middle managers' self-reported perspectives. The first five activities confirmed traditional descriptions in extant literature of the practices of middle managers relating to the planning, organising and controlling activities in support of strategies developed higher up in the organisation. However, two additional activities emerged namely 'advocacy' and 'improving operational practice'. These new roles were explored in more detail during the focus group discussions.

\section{Advocacy during strategy implementation}

The role of 'advocacy' highlighted the role of middle managers as boundary spanners that have interactions with internal and external stakeholders, and who see it as their responsibility to ensure that the strategy is known and understood by key stakeholders. It mirrors the findings of Rouleau (2005), who found that middle managers interpret and create sense for themselves and then communicate their thoughts to others to gain their support. In the South African public sector context, participants agreed that many of the strategies are conceptualised as policy decisions. At policy development level, there is generally agreement about the outcome of such a policy. However, the question about 'what that policy means in practice' seems not to be addressed. Middle managers, as implementers, therefore need to identify a number of stakeholders and work streams in order to 'crystalise' the policy into a specific strategy and to ensure 'buy-in' across the different stakeholder groups. Participants, in the public sector focus group, strongly agreed that if middle managers do not take ownership of policies and advocate the merits of strategies in support of these policies, implementation would be doomed in the public sector context. To contextualise this role, one participant referred to a decision to modernise the legacy systems in the department where he works.

The strategy was to replace the legacy systems on the customs side. Customs involve a number of stakeholders, both internal and external; it also involves other agencies and companies. So when implementing strategies, it is something you cannot do as one government department. Also internally, you got quite a number of stakeholders, people that have been doing the job for a number of years and those who are subject specialist and you have to bring them all on board to design the new systems. Once it is designed you need to sell those designs to the executive committee or the programme steering committee. Once the designs are understood internally you can go out and sell that particular change to the external stakeholders. This process required us to set up quite a number of work streams, for example, the legal work stream, the HR and change work stream, the systems work stream, the process work stream and so on to show that this thing takes place within the ambit of project management.

Other participants strongly related to this statement and indicated that strategy implementation was a dual process. Middle managers often receive instructions from policy makers and they are expected to get support for the policy on ground level, then operationalise the strategy within a project management process, and then required to re-sell the revised strategy back to the policy makers. One participant summarised this role as follows:

Many times you got this re-engineering almost that has to happen before it can be implemented. To advocate you have to take ownership of the policy and take accountability. Yet, you don't engage in strategy making so it is very difficult to understand where the policy is coming from or the change drivers which is required. It is almost a change initiative that you need to do first and after that you need to advocate.

Participants, in the private sector focus group, concurred that advocacy is important, but findings suggest that the process of advocacy is done on a more collective basis. One participant, for example, indicated that her company makes use of road shows to sell the strategies to internal and external stakeholders whilst other participants referred to formal engagement sessions with stakeholders. Middle managers indicated that they were active participants in these initiatives and often play leading roles during execution. The findings with regard to advocacy suggest that middle managers in the public sector seem to embrace advocacy (especially with regard to implementing government policies) as a more natural role than private sector middle managers do. 


\section{Improving operational practice during strategy implementation}

Participating middle managers also suggested that 'improving operational practice' is a key part of their responsibilities. In the context of the South African public sector, focus group participants indicated that the role of improving operational practises often involves 'one-directional' initiatives which do not benefit from the support of sub-ordinates or the political power from superiors. Middle managers are often required to take risks and responsibilities and then suffer the deteriorating relationships that often follow the outcomes of projects. An illustrative example was provided by a participant who undertook initiatives to drive operational costs down. After analysing expenditure patterns, she realised that telephone bills were abnormally high. She came up with an initiative to control telephone usage and expenditure. However, she highlighted that this self-initiated project presented unique challenges.

You are coming across situations where the same people who are responsible to assist you with the implementation of a system to monitor telephone usage, are the same people who are abusing the system. So you can understand how difficult it is; they come with all kinds of excuses to say that they can't find a suitable provider or that the providers are not responding. So you have to take risks and do it yourself but the unions will revolt against it and say that you did not follow the procedures and all those things. Then you have to make sure that you effect change management quickly because in the process of implementing that decision you have to deal with all these noises that are coming from everywhere.

All participants related to this example and furthermore suggested that although they are often expected to identify value adding initiatives they are neither rewarded nor supported for their resourcefulness. Instead they are required to take full accountability for projects which are then added to 'normal workloads' and performance targets. This approach often leads to middle managers disengaging from strategic contributions. More positive sentiments were expressed by participants from the private sector focus group. Participants in this group strongly associated this role with leadership and indicated that they had a personal interest to improve overall performance. A participant explained that in supporting the strategy, he ensures that the overall performance of the organisation improves. He explained: I do this by training our managers and developing tools and policies to ensure that we have consistent application across the group'. This role of improving operational practice, ranged from being assigned special projects to using their own initiative to find ways of improving operational efficiencies.

In this instance, private sector middle managers seemed to regard the drive for operational efficiencies as a natural consequence of their middle manager roles, while public sector middle managers associated such initiatives with risks and potential negative consequences.

\section{Interpreting and communicating information}

The role of interpreting and communicating information was identified by $50 \%$ of the participants as a middle manager role. Strategising activities considered in support of this role directly related to information compilation, transfer and interpretation. Table 3 includes the six strategising activities identified as well as verbatim quotes from data to illustrate middle managers' self-reported perspectives. This role was described with rich descriptions in the narrative suggesting that participants considered these practices as important. Participants did not only describe the strategising activities but they also expanded on strategising tools and contextual application. Furthermore, it was clear that information synthesis played an important role as only a few examples were found that indicated the transfer of information in its original, unchanged format. Key observations by the researchers included that upward sensegiving was mostly achieved when middle managers presented formal reports with key statistics on performance and compliance to their superiors. Middle managers were also asked for inputs during planning meetings and they contributed to strategic discussions through their functional knowledge and industry experience. Serving as linking pins between different operational levels, middle managers also functions as communication channels used to relate messages in an original format. Cases where information was retained in its original format were scarce and it was apparent that middle managers typically use their own interpretation to create relevance. The strategising activity of communicating referred to the manner in which middle managers communicated information. It was noted that various mediums were used for communication. These mediums included reports, public debates, workshops, meetings, social media, road shows, a departmental knowledge management portal and e-mails. Evidence suggests that middle managers carefully select mediums to achieve effective results. Middle managers also appear to be passionate about how they make sense of and in turn provide information to others about strategic initiatives. The upward, downward and lateral influence on information confirms the role of the middle manager as a strategic actor. 
Table 3. Interpreting and communicating information

\begin{tabular}{|c|c|}
\hline Strategising activity & Examples from data \\
\hline Upward sensegiving & $\begin{array}{l}\text { 'My role is to sit in on meetings with the top managers as they explain the } \\
\text { strategies they want to implement. Top managers are open for suggestions due } \\
\text { to the fact that they are aware that I have the knowledge about how the } \\
\text { company works. I am active in the worker's processes and sometimes oversee the } \\
\text { actual production. They are aware that I can detect threats and opportunities in } \\
\text { the company more easily than they can because we middle managers and front } \\
\text { line managers understand what goes into the physical work for the workers' }\end{array}$ \\
\hline $\begin{array}{l}\text { Relating messages } \\
\text { between subordinates } \\
\text { and management }\end{array}$ & $\begin{array}{l}\text { '...employees come to me with certain issues and I then pass these issues onto } \\
\text { top management where matters are taken further' '....communicate the message } \\
\text { from the board/CEO to our subordinate' }\end{array}$ \\
\hline \multirow[t]{2}{*}{ Communicating } & $\begin{array}{l}\text { 'My role is to lead and communicate messages in a way that they are taken } \\
\text { seriously and receive more attention' }\end{array}$ \\
\hline & $\begin{array}{l}\text { Regular updates on progress in terms of realising strategy through the available } \\
\text { internal communication channels also form part of my role, while coordination } \\
\text { of the road show sessions for direct staff interaction and the facilitations of two- } \\
\text { way communication is a key imperative. }\end{array}$ \\
\hline Sensemaking & $\begin{array}{l}\text { 'My role is to basically understand the strategies set out by top management. } \\
\text { Once I have fully understood what needs to be done I then discuss this with my } \\
\text { other two middle managers. Once we have discussed the agenda it is my role to } \\
\text { sit in with front line managers and explain to them what top management } \\
\text { requires from the workers as well as the overall organisation. So my role is to } \\
\text { translate the strategies from the top management to the front line managers on } \\
\text { the factory floor' }\end{array}$ \\
\hline \multirow[t]{2}{*}{$\begin{array}{l}\text { Downward } \\
\text { sensegiving }\end{array}$} & $\begin{array}{l}\text { Often, the strategic goals are laid out in such technical jargon that general staff } \\
\text { do not understand and it is my duty to translate this into a language that they } \\
\text { can understand or relate to' }\end{array}$ \\
\hline & $\begin{array}{l}\text { Within this, it is important to also drive the strategy into action by ensuring that } \\
\text { everyone understands the objectives and the picture of success of not only the } \\
\text { trade deliverables, but also individual activities' }\end{array}$ \\
\hline
\end{tabular}

\section{Facilitating adaptability}

Approximately $30 \%$ of participants indicated that they engaged in some form of facilitating adaptability aimed at improving strategising activity. As indicated in Table 4, three activities were identified to support this role: crafting change, creating strategy and integration.

Table 4. Facilitating adaptability

\begin{tabular}{|l|l|}
\hline Strategising activity & Examples from data \\
\hline Crafting change & $\begin{array}{l}\text { 'As a leader my main drive is being a change agent as change can be guaranteed to } \\
\text { take place on an on-going basis as organisations make continuous improvement to } \\
\text { enhance their internal (systems/processes) and external (new products or service } \\
\text { level improvements and/or improved product features) offerings and to make } \\
\text { them better' }\end{array}$ \\
\hline Integration & $\begin{array}{l}\text { 'My role is contributing to the formulation of the strategy before the senior } \\
\text { management team finalises the strategy' }\end{array}$ \\
\hline $\begin{array}{l}\text { 'My mandate relates to developing economic and trade strategies and country } \\
\text { analyses for the region I am responsible for. Through these I am able to capture } \\
\text { recommended actions and steps. This requires consultation with the industry } \\
\text { stakeholders within various sectors and takes their input into account. We are also, } \\
\text { through certain platforms able to raise concerns of our domestic players in } \\
\text { accessing the markets of our trading counterparts' }\end{array}$ \\
\hline
\end{tabular}

As a social craftsperson, the middle manager takes the responsibility of crafting change in order to improve working practices or to react to external environmental changes. Middle managers also contribute to creating strategy, extending their traditional role as implementers to include the role of strategy formulators, albeit generally in conjunction with the top management team. Finally, the findings also show that middle managers are social actors that engage with internal and external networks in an attempt to benefit from alternative perspectives and collaborations to improve their own practices. 


\section{Downward supporting}

The themes derived from the data supported the roles identified in the literature review, and include three strategising activities, namely emotional balancing, creating continuity and professional support. The responses from $27 \%$ of participants identified two additional activities, namely to manage performance and to drive compliance. A description of these activities as well as supporting data is presented in Table 5.

Middle managers felt responsible for providing emotional support to subordinates. Taking an active interest in staff members' morale involved employing practices such as mentoring and coaching as well as using their people skills to ensure that staff members are motivated and understand their role in achieving strategic plan targets. Middle managers also acknowledged their roles as facilitators of change, contributing in their sphere of influence to create continuity. In order to provide professional support, middle managers indicated that they strive to proactively empower staff members with the necessary skills, tools, and resources to do their jobs. The two new activities that emerged were 'manage performance' and 'drive compliance'.

\section{Managing performance}

Managing performance in this instance goes beyond merely monitoring performance to include regular contact and reviews with staff with a view to identifying and addressing weaknesses and providing support for improving performance. During the focus group discussions it emerged that middle managers employed in the South African public and private sectors often observe that newly appointed staff members lacked basic skills expected from employees appointed on a particular job level. As a result, participants indicated that they would often take time to conduct 'on-the-job' training and focus on skills that should ideally have been in place.

All participants agreed that in the South African public sector a great deal of sensitivity is required when managing performance outside the formal structures and systems. Formal processes would typically deal with performance related to actions that are monitored and scored and informal approaches are used to address quality adherence to expected standards. One of the participants indicated that he has 'very informal chats' to understand how his subordinates are doing and whether they have any challenges within the workplace. ...chats will start with how you are, what is happening and then what are the issues here. Then we will talk about the issues and I will pick up some of the things that will not come up during formal discussions but staff is more likely to open up during these small chats. You will realise that the person will need assistance here. Then you confront it in a nice relaxed way, and you will say that, by the way, we need to look at how we approach this particular aspect in our work and I believe that there could probably be some improvement, what do you think?

Table 5: Downward supporting

\begin{tabular}{|c|c|}
\hline Strategising activity & Examples from data \\
\hline Emotional balancing & $\begin{array}{l}\text { 'Boosting morale. When employees are demotivated and unable to meet short } \\
\text { term goals. It is important to coach and boost confidence in employees to } \\
\text { work towards the goals' }\end{array}$ \\
\hline Creating continuity & $\begin{array}{l}\text { 'In this role, I act as facilitator of change. I remove obstacles like contradictory } \\
\text { goals to ensure the required resources are in place. Behaviours reflecting, } \\
\text { discussing and empowering personnel are included' }\end{array}$ \\
\hline Professional support & $\begin{array}{l}\text { 'It is also my role to ensure that all team members receive the right level of } \\
\text { development needed to maximise their individual performance and maximise } \\
\text { retention' }\end{array}$ \\
\hline $\begin{array}{l}\text { Managing } \\
\text { performance }\end{array}$ & $\begin{array}{l}\text { Moreover, I have to ensure that my team meets their objectives. I do this by } \\
\text { scheduling regular time with them to ensure they are on track as well as having } \\
\text { mid-year and year-end reviews. It is crucial to not leave the review for every } 6 \\
\text { months but to be in regular contact with your team' 'I often assist with } \\
\text { performance improvement on the people's side and I handle the performance } \\
\text { appraisals' }\end{array}$ \\
\hline Driving compliance & $\begin{array}{l}\text { 'An example is when the cost of sales at one of our stores was too high and this } \\
\text { affected the profitability. I had to go in and investigate and find out why things } \\
\text { were not going as planned. I found out that managers were not taking their } \\
\text { responsibility seriously and that there was a high amount of wastage of } \\
\text { inventory. I then put measures in place to prevent losses and took disciplinary } \\
\text { action against those who were failing to adhere to company procedure' } \\
\text { 'Thereafter all the role-players will be expected to report on the process. Each } \\
\text { role- player will have to report progress at the monthly branch and trainers' }\end{array}$ \\
\hline
\end{tabular}




\begin{tabular}{|l|l|}
\hline & $\begin{array}{l}\text { meetings. Where the progress of those employees reporting to me is not } \\
\text { satisfactory I will take corrective steps. Where the progress is on or ahead of time } \\
\text { and on budget I will give positive feedback }\end{array}$ \\
\hline
\end{tabular}

Focus group discussions with participants employed in the South African private sector revealed that support required to manage performance often goes beyond professional. One participant indicated that his staffs 'also trust me with their personal problems'.

\section{Driving compliance}

Driving compliance also dealt with staff performance levels and methods to evaluate, control and monitor staff performance. Most notable were several quotes indicating that middle managers conducted performance appraisals and used disciplinary actions and rewards to modify behaviour. These roles specifically dealt with human aspects of performance and differed from activities employed to control strategy implementation that focused on strategic processes. The focus group discussions revealed that in the South African public and private service, compliance is mostly driven by clear measurement of expected performance areas. However, participants indicated that 6 monthly reviews and annual performance contracting are not sufficient to manage performance. Staff members expect continuous feedback about their performance and if this only happens twice a year they accept that their performance is on the expected standard. What you are referring to has become orthodox where you wait for six months for a review. Organisations has realised that waiting for such long periods is crippling organisations and performance. I work in an environment where we have one-on-one's every two months to understand where I am and where are we going. Another participant revealed that, in his department, staff contracts on a monthly basis and that scorecards are completed at the end of that month. This process allows staff members to track performance over time and avoid situations where staff members only perform towards the end of the year.

Although it is widely known that the South African government sector prefers to dismiss non- performers, participants indicated that this notion is changing. When work does not get done and it becomes systematic many public sector organisations implement a 'performance enhancement programme'. Once nonperformers are placed on a performance enhancement programme they receive additional training and 'on-the-job' mentoring and 'you either improve or you are shipped out'. The performance enhancement programme thus ultimately leads to dismissal if performance is not on the expected standard. On the other extreme, participants also expressed that performance are recognised through 'on-the-spot' recognitions, competitions and annual awards. The purpose of such recognition is to reward 'shining stars' and to emphasise that 'this person emulates the behaviour that we desire'. All these initiatives are initiated by line managers who are also required to take responsibility for the required actions.

Both focus groups highlighted that without an 'active, engaged mentoring type middle manager' it would be difficult to ensure compliance. While middle managers have the potential to establish values that can inculcate behaviour that will drive compliance, tools like performance management are simply a checklist. Participants in both public and private sectors concurred that compliance is thus the result of engaged middle managers that provides regular and constructive feedback to staff members which will enable them to improve their performance. It was of interest to note, that the private sector participants appreciated the value of employee induction programmes and the alignment between employee values with organisational values.

\section{Upward influencing}

Only $21(3.2 \%)$ participants indicated that they engaged in upward influencing. These participants related upward influencing to two strategising activities, namely championing alternatives and influencing strategic issues. A description of these activities as well as supporting verbatim quotes from middle managers is contained in Table 6.

\section{Table 6. Upward influencing}

\begin{tabular}{|l|l|}
\hline Strategising activity & Examples from data \\
\hline $\begin{array}{l}\text { Championing } \\
\text { alternatives }\end{array}$ & $\begin{array}{l}\text { 'I have a long term vision of what should change in my portfolio to make a } \\
\text { difference. The big challenge is to sensitise all stakeholders before you sell a } \\
\text { strategy or idea to them. Top management must support your vision as } \\
\text { without them all efforts are hopeless' }\end{array}$ \\
\hline $\begin{array}{l}\text { Influencing strategic } \\
\text { issues }\end{array}$ & $\begin{array}{l}\text { 'I must also provide relevant, market related strategic factors to EXCO } \\
\text { [executive committee] to facilitate effective strategy formulation' }\end{array}$ \\
\hline
\end{tabular}


Championing alternatives related to self-initiated strategies that required buy-in from top management and other stakeholders prior to implementation. The second activity, to influence strategic issues, differs from 'upward sensegiving' and 'relating messages between subordinates and management' identified as strategic activities within the role of 'managing and channelling information' as it relates to activities that are self-initiated and involve conceptual interpretation of existing information. From this perspective, it is evident that some middle managers see their role in strategy as being critics of the organisation and its strategies, and take responsibility for airing their views to top management. This role resonates with the notion of issue-selling (Dutton \& Ashford, 1993). Following the findings presented above, the article concludes with a discussion of the theoretical and managerial implications and directions for future research.

\section{CONCLUSIONS}

The aim of the research was to determine the self-perceived strategic roles of middle managers, and collected 654 responses from South African middle managers representing a wide range of sectors, industries and types of organisations, as well as from two focus groups conducted with 20 middle managers representing both private and public sector organisations. The responses were categorised into five broad middle manager roles as identified in the literature review, and the frequency of responses (based on the number of respondent mentioning the role or one of its sub-categories) is outlined in Figure 2.

From Figure 2 it is apparent that South African middle managers overwhelmingly associate their strategic role with the 'traditional roles' of middle managers as implementers of strategies and communicators linking their subordinates and higher levels of management. This may have a lot to do with their training and education, as most training institutions in South Africa would favour microeconomic and process perspectives on strategy. In addition, the South African cultural disposition towards respect for power, position and authority may also contribute to these perceptions. However, realities in the South African business environment have also influenced the nature of the implementation role of middle managers. In addition to the traditional middle manager role of planning, organising, leading and controlling to ensure the successful implementation of strategy, we added the roles of 'advocacy' and 'improving operational practice'.

Advocacy is a role that seems to be is especially prevalent in the public sector, where middle managers often assume responsibility for interpreting and 'selling' government policies to a variety of stakeholders. In such a role (from a public sector perspective), the influence of middle managers conceivably expands to affect and shape change not only in their own organisations, but also in society at large. In addition to the advocacy role described above, middle managers also reported that they see the drive to improve operational practice as a particular role of middle managers. Rather than simply implementing directives from the top management team, it involves the identification and targeting of specific areas for operational improvement by middle managers themselves as a means of contributing to organisational success.

With regard to communication, we confirm the existing theoretical perspectives that middle managers are often more than just relayers of messages between the top and bottom of the organisation, and that they mostly act as translators of strategy for the benefit of internal and external stakeholders, and as a sounding board for strategic ideas and initiatives from top managers. A significant percentage of participants (around 30\%) indicated that they saw their roles as facilitating adaptability and providing support to their subordinates (downward influencing), but given the increasing requirement for organisational flexibility and talent management, this number is actually surprisingly low. When engaging the facilitating adaptability role, middle managers may initiate certain strategic activities (e.g., in reaction to external changes) or participate in strategy- making alongside the top management team. They are also seen in this role as being networkers that collaborate with internal and external networks to improve practice. With regard to their downward influence, our findings support the theoretical perspectives that middle managers provide both emotional and professional support to their subordinates. However, during the focus groups the lack of skills in the South African business environment did seem to necessitate middle managers engaging more in 'managing performance' and developing the skills of their subordinates (both formally and informally) and in 'driving compliance' by modifying subordinate behaviour to be more in line with organisational requirements. A very small number of participants (3\%) indicated that their middle management role includes some aspect of upward influencing. 
This was mostly in the form of championing alternatives (Mantere, 2005, 2008) or as self-appointed critics of the organisation and its strategies, alerting the top management team to areas for improvement or change. It is important for middle managers to be aware of and enact the broader strategic role that a changing business environment requires them to fulfil. This awareness needs to be created by universities and training institutions, which will need to incorporate perspectives emphasising strategising as a human activity in their curricula. It is also important to understand the cultural and other constraints on expanding the middle management role in the South African context, and this provides a rich vein for future research. Middle managers have the potential to influence the strategy agenda and the strategies of organisations, but if they are constrained by traditional perspectives of what middle managers are supposed to do, this potential will not be realised.

Figure 2. Strategic Roles of South African Middle Managers

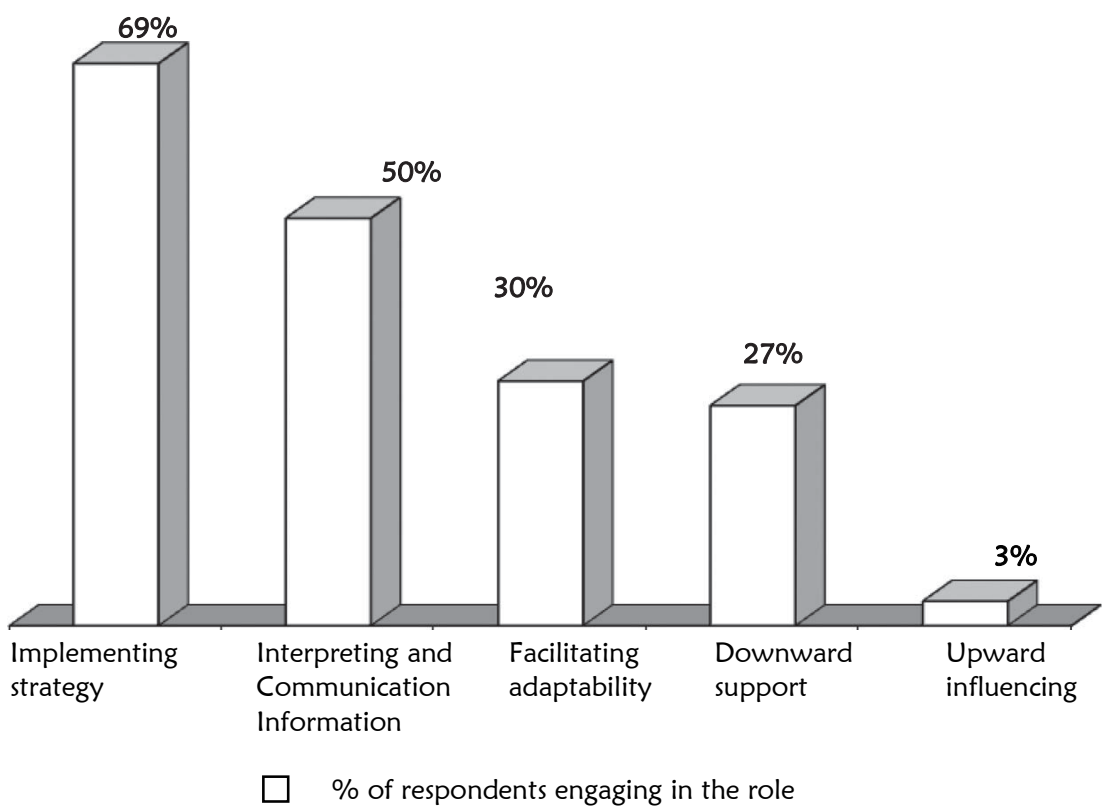

The study was limited by the fact that the majority of data were collected by relatively inexperienced interviewers, although additional focus groups were conducted to mitigate this shortcoming. In addition, the study is situated in South Africa and it may not be possible to relate the findings to other contexts. Despite these limitations the study delivered some promising and interesting findings, and it does open up several opportunities for future research. An obvious opportunity exists in the possibility of repeating the study in other contexts and to compare the findings across contexts. In addition, more specific research on the practices of middle managers with regard to the roles identified will shed light on how these roles are enacted by middle managers and will help us to develop a better understanding of how middle managers perceive their strategic role.

\section{ACKNOWLEDGEMENTS}

The authors thank two anonymous reviewers for their extensive and useful comments. 


\section{References}

Balogun, J. (2007). The practice of organizational restructuring: From design to reality. European Management Journal, 25(2), 81-91.

Balogun, J., \& Johnson, G. (2004). Organizational restructuring and middle manager sensemaking. The Academy of Management Journal, 47(4), 523-549.

Barry, D., \& Elmes, M. (1997). Strategy retold: Toward a narrative view of strategic discourse. The Academy of Management Review, $22(2), 429-452$.

Braun, V., \& Clarke, V. (2006). Using thematic analysis in psychology. Qualitative Research in Psychology, 3(2), 77-101. Briggs, A. R. J. (2005). Middle managers in English further education colleges. Educational Management Administration \& Leadership, 33(1), 27-50.

Burgelman, R. A. (1983). A model of the interaction of strategic behaviour, corporate context, and the concept of strategy. Academy of Management R evi e w, 8(1), 61-70.

Carney, M. (2004). Middle manager involvement in strategy development in not-for profit organizations: The director of nursing perspective - How organizational structure impacts on the role. Journal of Nursing Management, 12(1), 13-21.

Carpenter, M. A. (2002). The implications of strategy and social context for the relationship between top management team heterogeneity and firm performance. Strategic Management Journal, 23(3), 275-284.

Carter, C., Clegg, S. R., \& Kornberger, M. (2008). Soapbox. Editorial essays: Strategy as practice? Strategic Organization, 6(1), 83-99.

Chia, R., \& Holt, R. (2006). Strategy as practical coping: A Heideggerian perspective. Organization Studies, 27(5), $635-655$.

Cohen, L., Manion, L., \& Morrison, K. (2000). Research methods in education (5th ed.). New York, NY: Routledge Falmer.

Costanzo, L. A., \& Tzoumpa, V. (2008). Enhancing organisational learning in teams: Has the middle manager got a role?. Team Performance Management, 14(3/4), 146-164.

Creswell, J. W. (2013). Qualitative inquiry and research design: Choosing among five approaches (3rd ed.). Thousand Oaks, CA: Sage.

Currie, G., \& Procter, S. J. (2005). The antecedents of middle managers' strategic contribution: the case of a professional bureaucracy. Journal of Management Studies, 42(7), 1325-1356.

Dutton, J. E., \& Ashford, S. J. (1993). Selling issues to top management. The Academy of Management Review, 18(3), 397-428.

Dutton, J. E., Ashford, S. J., O’Neill, R. M., Hayes, E., \& Wierba, E. E. (1997). Reading the wind: How middle managers assess the context for selling issues to top managers. Strategic Management Journal, 18(5), 407-423.

Dutton, J. E., Ashford, S. J., O’Neill, R. M., \& Lawrence, K. A. (2001). Moves that matter: Issue selling and organizational change. Academy of Management Journal, 44(4), 716-736.

Floyd, S. W., \& Wooldridge, B. (1992). Middle management involvement in strategy and its association with strategic type: A research note. Strategic Management Journal, 13(S1), 153-167.

Floyd, S. W., \& Wooldridge, B. (1994). Dinosaurs or dynamos? Recognizing middle management's strategic role. The Academy of Management Executive, 8(4), 47-57.

Floyd, S. W., \& Wooldridge, B. (1999). Knowledge creation and social networks in corporate entrepreneurship: The renewal of organizational capability. Entrepreneurship: Theory and Practice, 23, 1-21.

Floyd, S. W., \& Wooldridge, B. (2000). Building strategy from the middle. Thousand Oaks, CA: Sage.

Floyd, S. W., \& Wooldridge, B. (2003). Middle management's strategic influence and organizational performance. Journal of Management Studies, 34(3), 465-485.

Hambrick, D. C. (2007). Upper echelons theory: An update. Academy of Management Review, 32(2), 334-343. Hambrick, D. C., \& Mason, P. A. (1984). Upper echelons: The organization as a reflection of its top managers. The Academy of Management Review, 9(2), 193-206.

Herzig, S. E., \& Jimmieson, N. L. (2006). Middle managers' uncertainty management during organizational change. Leadership \& Organization Development Journal, 27(8), 628-645.

Huy, Q. N. (2001). In praise of middle managers. Harvard Business Review, 79(8), 72-79. 
Huy, Q. N. (2002). Emotional balancing of organizational continuity and radical change: The contribution of middle managers. Administrative Science Quarterly, 47(1), 31-69.

Ikävalko, H. (2005). Strategy process in practice: Practices and logics of action of middle managers in strategy implementation. Helsinki: Unpublished doctoral dissertation, Helsinki University of Technology.

Janesick, V. J. (2000). The choreography of qualitative research design: Minuets, improvisations, and crystallization. Handbook of qualitative research (2nd ed). 379-399.

Jarzabkowski, P. (2003). Strategic practices: An activity theory perspective on continuity and change. Journal of Management Studies, 40(1), 23-55.

Jarzabkowski, P. (2004). Strategy as practice: Recursiveness, adaptation, and practices-in-use. Organization Studies, 25(4), 529-560.

Jarzabkowski, P. (2005). Strategy as practice: An activity-based approach. London: Sage.

Jarzabkowski, P., Balogun, J., \& Seidl, D. (2007). Strategizing: The challenges of a practice perspective. Human Relations, 60(1), 5-27.

Johnson, G., Langley, A., Melin, L., \& Whittington, R. (2007). Strategy as practice: Research directions and resources. Cambridge: Cambridge University Press.

Johnson, G., Whittington, R., \& Scholes, K. (2011). Exploring strategy: Text \& cases (9th ed.). Upper Saddle River, NJ: Financial Times: Prentice Hall.

Karger, D. W., \& Malik, A. A. (1975). Long range planning and organizational performance. Long Range Planning, 8(6), 60-64.

Kodama, M. (2005). Knowledge creation through networked strategic communities: Case studies on new product development in Japanese companies. Long Range Planning, 38(1), 27-49.

Kuratko, D. F., Ireland, R. D., Covin, J. G., \& Hornsby, J. S. (2005). A model of middle-level managers' entrepreneurial behaviour. Entrepreneurship Theory and Practice, 29(6), 699-716.

Labuschagne, A. (2003). Qualitative research: Airy fairy or fundamental? The Qualitative Report, 8(1), 100-103. Ling, Y.,

Floyd, S. W., \& Baldridge, D. C. (2005). Towards a model of issue-selling by subsidiary managers in multinational organizations. Journal of International Business Studies, 36, 637-654.

Lyles, M. A., \& Schwenk, C. R. (2007). Top management, strategy and organisational knowledge structures. Journal of Management Studies, 29(2), 155-174.

Mantere, S. (2005). Strategic practices as enablers and disablers of championing activity. Strategic Organization, 3(2), 157-184. Mantere, S. (2008). Role expectations and middle manager strategic agency. Journal of Management Studies, 45(2), 294-316.

Mantere, S., \& Vaara, E. (2008). On the problem of participation in strategy: A critical discursive perspective. Organization Science, 19(2), 341-358.

Marginson, D. E. W. (2002). Management control systems and their effects on strategy formation at middle- management levels: Evidence from a UK organization. Strategic Management Journal, 23(11), 1019-1031.

McNaught, C., \& Lam, P. (2010). Using Wordle as a supplementary research tool. The Qualitative Report, 15(3), 630-643.

Mills, C. W. (1956). White collar: The American middle class. New York, NY: Oxford University Press. Mouton, J. (2006). How to success in your master's and doctoral studies. Pretoria: Van Schaik.

Nonaka, I. (1988). Toward middle-up-down management: Accelerating information creation. Sloan Management Review, 29(3), 9-18.

Nonaka, I. (1994). A dynamic theory of organizational knowledge creation. Organization Science, 5(1), $14-37$.

Nordqvist, M., \& Melin, L. (2008). Strategic planning champions: Social craftspersons, artful interpreters and known strangers. Long Range Planning, 41(3), 326-344.

O'Shannassy, T. (2003). Modern strategic management: Balancing strategic thinking and strategic planning for internal and external stakeholders. Singapore Management Review, 25(1), 53-67.

Osterman, P. (2008). The truth about middle managers: Who they are, how they work, why they matter. Boston, Massachusettes: Harvard Business School Press.

Papadakis, V. M., Lioukas, S., \& Chambers, D. (1998). Strategic decision-making processes: The role of management and context. Strategic Management Journal, 19(2), 115-147. 
Raes, A. M., Heijltjes, M. G., Glunk, U., \& Roe, R. A. (2011). The interface of the top management team and middle managers: A process model. Academy of Management Review, 36(1), 102-126.

Rouleau, L. (2005). Micro-practices of strategic sensemaking and sensegiving: How middle managers interpret and sell change every day. The Journal of Management Studies, 42(7), 413-1441.

Rouleau, L., \& Balogun, J. (2011). Middle managers, strategic sensemaking, and discursive competence. Journal of Management Studies, 48(5), 953-983.

Saldaña, J. (2009). The coding manual for qualitative researchers. Thousand Oaks, CA: Sage.

Schwandt, T. (1998). Constructivist, interpretivist approaches to human enquiry. In N. K. Denzin \& Y. S. Lincoln (Eds.), The Landscape of Qualitative Research. London: Sage, 221-259.

Van de Ven, A. H. (1992). Suggestions for studying strategy process: A research note. Strategic Management Journal, 13(Summer), 169-191.

Westley, F. R. (1990). Middle managers and strategy: Micro dynamics of inclusion. Strategic Management Journal, 11(5), 337-351.

Whittington, R. (2003). The work of strategizing and organizing: For a practice perspective. Strategic Organization, 1(1), 117-126.

Wiersema, M. F., \& Bantel, K. A. (1992). Top management team demography and corporate strategic change. The Academy of Management Journal, 35(1), 91-121.

Wooldridge, B., Schmid, T., \& Floyd, S. W. (2008). The middle management perspective on strategy process: Contributions, synthesis, and future research. Journal of Management, 34 (6), 1190-1221. 